\title{
ANALYSIS OF THE EFFICIENCY OF TRADE IN OIL DERIVATIVES IN SERBIA BY APPLYING THE FUZZY AHP-TOPSIS METHOD
}

\author{
Radojko Lukic \\ Faculty of Economics, University of Belgrade, Serbia \\ rlukic@ekof.bg.ac.rs
}

\begin{abstract}
The problem of analyzing trade efficiency is topical, significant and very complex. Multi-criteria decision-making has been increasingly used recently. With that regard, this paper analyzes the efficiency of trade in oil derivatives in Serbia with integrated application of the Fuzzy AHP-TOPSIS method. The results of this study show that of all the observed criteria (earnings, assets, capital, sales and net profit), the most significant are employees`earnings and capital respectively, and that the most effective companies are Daki Petrol, Oil Industry of Serbia (NIS), and Horizon Petrol. The most inefficient companies are Eko Serbia, Lukoil and Naftachem. In order to improve their efficiency in the future, it is necessary to manage assets, capital, sales and profits as efficiently as possible. Likewise, it is imperative that employees' earnings are at an "acceptable level" in accordance with the business conditions in a given business environment.
\end{abstract}

Keywords: employees` earnings, assets, capital, sales, profit.

\section{INTRODUCTION}

In order to obtain as accurate information as possible about the efficiency of trading companies, multicriteria decision-making has been increasingly used. With this in mind, the subject of this paper is an analysis of the efficiency of oil derivatives trading in Serbia by integrated application of the Fuzzy AHPTOPSIS method. Based on the real situation, the aim of this work is to propose adequate measures for improving the efficiency of oil derivatives trade in Serbia in the future.

When it comes to the general problem of the analysis of the efficiency (primarily in the manufacturing and financial sectors) by applying Fuzzy AHP-TOPSIS method, the literature is extensive. However, there are very few papers dedicated to the application of Fuzzy AHP-TOPSIS method in the analysis of trading companies' efficiency (Keener, 2013; Martino et al. 2017). This is especially true of literature in Serbia and, as far as we know, there is almost no comprehensive work dedicated to the application of Fuzzy AHP-TOPSIS method in the analysis of the efficiency of trading companies, except for partial consideration in some papers dealing with efficiency measurement and cost management (Lukic, 2011; Lukic, 2018a,b; Lukic, 2019). Gap should be partly filled by this paper devoted to the analysis of the 
efficiency of trade in oil derivatives in Serbia by applying the Fuzzy AHP - TOPSIS method, thus making useful scientific and professional contribution.

The basic hypothesis of the research in this paper is that continuous monitoring of the efficiency of all companies, including trade companies, and taking adequate measures is a key basis for improvement in the future. Speaking of methodology, in addition to statistical analysis, econometric analysis and other mathematical methods and models, the analysis of the efficiency of trading companies (in our case sales of oil derivatives in Serbia) can be significantly improved by the integrated use of the Fuzzy AHP. TOPSIS method. In order to conduct the analysis in this paper, we collected the data from the Business Registers Agency of the Republic of Serbia which are "manufactured" in accordance with relevant international standards, so that there are no restrictions on international comparability.

\section{FUZZY AHP METHOD}

Multi-criteria decision making by applying the AHP (Analytical Hierarchical Process) method was developed with the fuzzy approach, which is known as the Fuzzy AHP method. The fuzzy AHP method combines the fuzzy concept with the AHP method. This method was developed by Chang (1996) using triangular fuzzy numbers (TFN). Let us denote the set of objects by $X=\left(x_{1}, x_{2}, \ldots, x_{n}\right)$, and the set of goals by $U=\left(u_{1}, u_{2}, \ldots, u_{m}\right)$. According to the Extended Analysis methodology (developed by Chang), an extended target analysis $u_{i j}$ is performed for each object. The value of the extended analysis $m$ for each object is expressed as follows:

$$
M_{g i}^{1}, M_{g i}^{2}, M_{g i}^{m}, i=1,2, \ldots, n
$$

where

$$
m_{g_{2}}^{j} j=1,2, \ldots, m \text { are fuzzy triangle numbers. }
$$

Figure 1 shows a fuzzy triangle number, as a combination of two lines. 
Lukic, $\mathbf{R}$.

ANALYSIS OF THE EFFICIENCY OF TRADE IN OIL DERIVATIVES IN SERBIA BY APPLYING THE FUZZY AHP-

TOPSIS METHOD

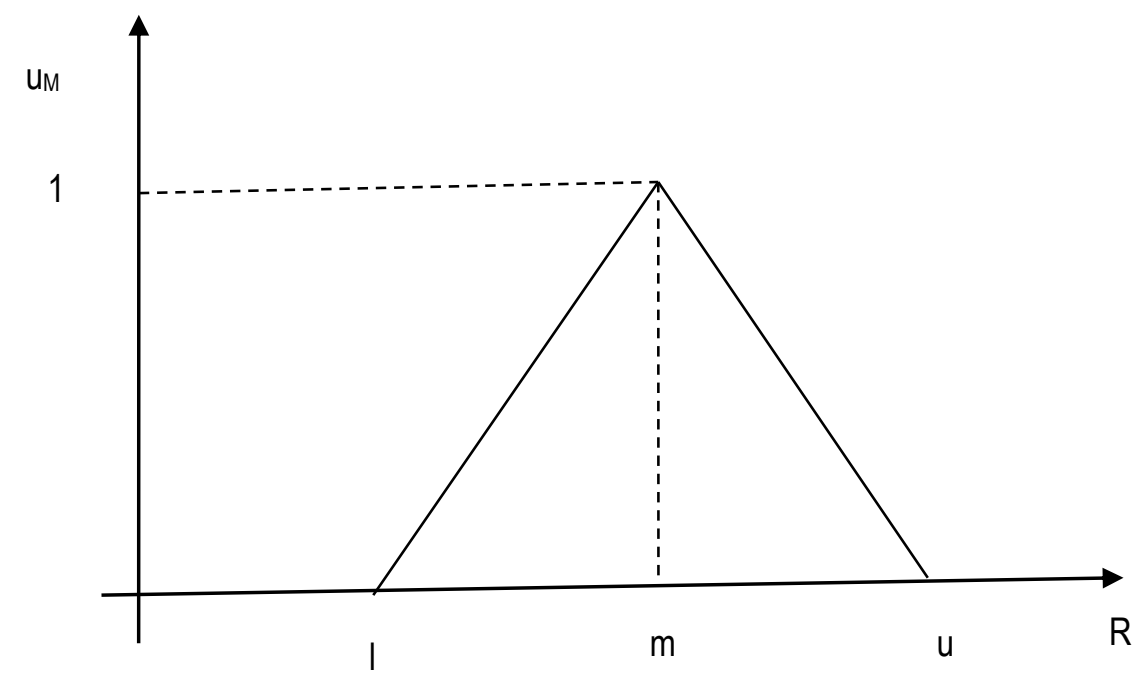

FIGURE 1. TRIANGULAR FUZZY NUMBER $M=(l, m, u)$

Source: van Laarhoven, P. J. M., and Pedrycs, W. (1983)

Chang's extended analysis contains the following steps (Chang, 1992, 1996; Zhu et al., 1999; Büyüközkan et al., 2004):

Step 1: fuzzy extensions values (fuzzy synthetic exten) for the $i$ object is defined as

$S_{i}=\sum_{j=1}^{m} M_{g i}^{j} \times\left[\sum_{i=1}^{n} \sum_{j=1}^{m} M_{g i}^{j}\right]^{-1}$

In order to obtain expression

$\sum_{j=1}^{m} M_{g i}^{j}$

it is necessary to perform additional fuzzy operations with $m$ values of the extended analysis such that

$\sum_{j=1}^{m} M_{g i}^{j}=\left(\sum_{j=1}^{m} l_{j}, \sum_{j=1}^{m} m_{j}, \sum_{j=1}^{m} u_{j}\right)$ 
and to obtain expression

$\left[\sum_{i=1}^{n} \sum_{j=1}^{m} M_{g i}^{j}\right]^{-1}$

it is necessary to make additional fuzzy operations with $M_{g i}^{j}(j=1,2, \ldots, m)$ values so that

$\sum_{i=1}^{n} \sum_{j=1}^{m} M_{g i}^{j}=\left(\sum_{j=1}^{m} l_{j}, \sum_{j=1}^{m} m_{j}, \sum_{j=1}^{m} u_{j}\right)$

and then determine the inverse vector in equation (4) as

$$
\left[\sum_{i=1}^{n} \sum_{j=1}^{m} M_{g i}^{j}\right]^{-1}=\left(\frac{1}{\sum_{i=1}^{n} u_{i}}, \frac{1}{\sum_{i=1}^{n} m_{i}}, \frac{1}{\sum_{i=1}^{n} l_{i}}\right)
$$

Step 2: Degree of possibility $M_{2}=\left(l_{2}, m_{2}, u_{2}\right) \geq M_{1}=\left(l_{1}, m_{1}, u_{1}\right)$ is defined as

$$
V\left(M_{2} \geq M_{1}\right)=\sup \left[\min \left(u_{m 1}(x), u_{m 2}(y)\right)\right]
$$

$y \geq x$

and can be expressed equivalently as

$$
V\left(M_{2} \geq M_{1}\right)=\operatorname{hgt}\left(M_{1} \cap M_{2}\right)=u_{m 2}(d)
$$

$$
=\left\{\begin{array}{c}
1 \text { ako jem } m_{2} \geq m_{1} \\
0 \quad \text { ako je } l_{1} \geq u_{2} \\
\frac{l_{1}-u_{2}}{\left(m_{2}-u_{2}\right)-\left(m_{1}-l_{1}\right)}
\end{array}\right.
$$

where $d$ is the ordinate of the largest cross section at point $D$ between $u_{m 1}$ and $u_{m 2}$ (Figure 2). By comparing $M_{1}$ and $M_{2}$ we can see that the required values are $V\left(M_{1} \geq M_{2}\right)$ and $V\left(M_{2} \geq M_{1}\right)$. 


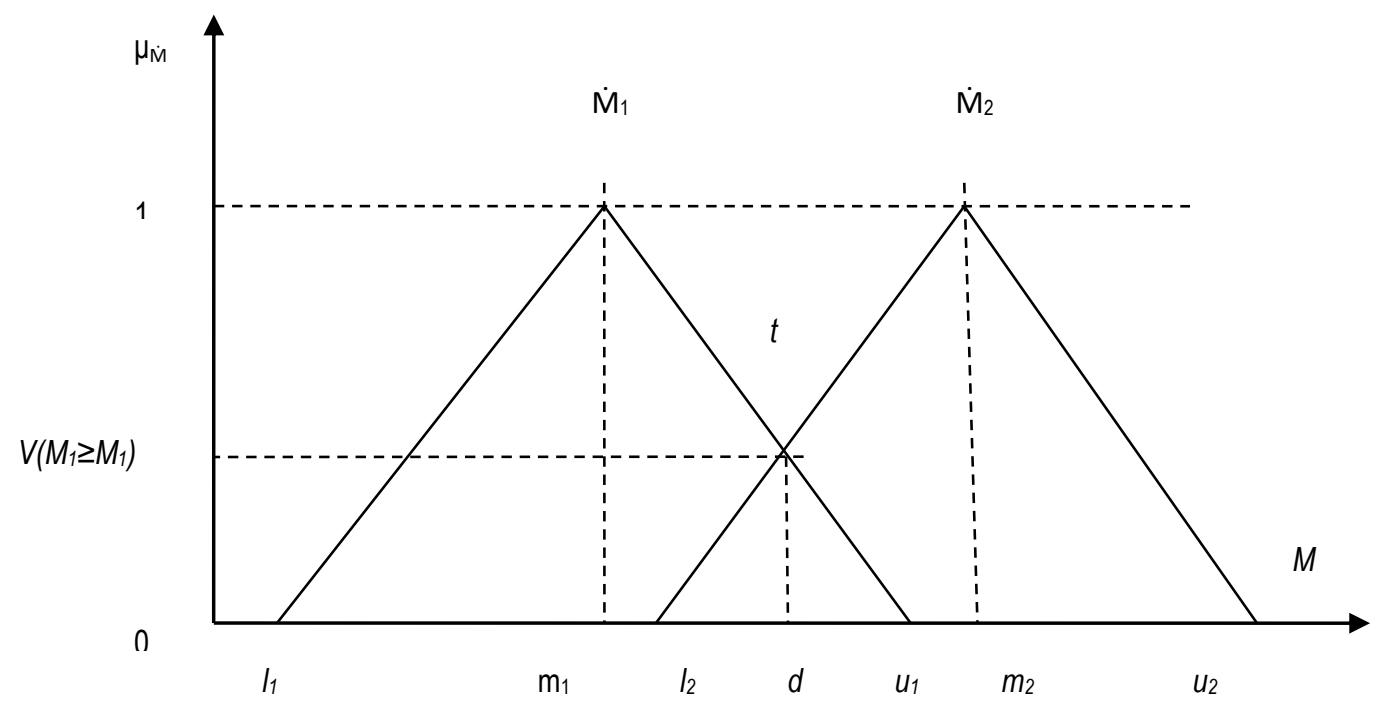

FIGURE 2. CROSS SECTION BETWEEN $M_{1}$ AND $M_{2}$

Source: author adaptation

Step 3: The degree of possibility for a convex fuzzy number, which should be greater than $k$ convex fuzzy number $M_{i}(i=1,2, \ldots, k)$, may be defined as:

$V\left(M \geq M_{1}, M_{2}, \ldots, M_{k}\right)=V\left[\left(M \geq M_{1}\right)\right.$ and $\left(M \geq M_{2}\right)$ and $\ldots$ and $\left.\left(M \geq M_{k}\right)\right]$

$=\min V\left(M \geq M_{1}\right)$

Let us assume that:

$d^{\prime}\left(A_{i}\right)=\min V\left(S_{i} \geq S_{k}\right)$

For $k=1,2, \ldots, n ; k \neq i$. Then the weighted vector is given as:

$W^{\prime}=\left[d^{\prime}\left(A_{1}\right), d^{\prime}\left(A_{2}\right), \ldots, d^{\prime}\left(A_{n}\right)\right]^{T}$

where $\mathrm{Ai}(i=1,2, \ldots, n)$ are $n$ elements.

Step 4: After normalization, normalized vectors are:

$W=\left[d\left(A_{1}\right), d\left(A_{2}\right), \ldots, d\left(A_{n}\right)\right]^{T}$

where $W$ does not represent fuzzy number. 
It is considered that the disadvantage of the Fuzzy AHP method is that is does not take into account the degree of consistency, i.e. does not calculate its value. It can be calculated by taking crisp values. Checking the degree of consistency of the Fuzzy AHP method can be done by applying the Kwong method (Kwong and Bai, 2003). The triangle number denoted as $M=(I, m, u)$ should be defuzzied as follows:

$$
M_{-c r s p}=\frac{(4 m+l+u)}{6}
$$

and apply the standard procedure for determining the degree of consistency as in the classical AHP method.

The application of the Fuzzy AHP method mitigates the shortcomings of the classic AHP method (Saaty, 1970, 1980, 2008, 1986; Saaty and Vargas, 2001; Harker and Vargas, 1987). Different fuzzy triangular comparison scales have been developed for this purpose, so that the decision maker can evaluate the significance of the criteria or alternative much closer and easier and thus minimize his "subjectivity" (Table 1).

TABLE 1. TRIANGULAR FUZZY SCALE (Chang, 1996)

\begin{tabular}{|l|l|l|}
\hline Linguistic variable & Triangular fuzzy scale & Triangular fuzzy reciprocal scale \\
\hline Just equal & $(1,1,1)$ & $(1,1,1)$ \\
\hline Equally important & $(1 / 2,1,3 / 2)$ & $(2 / 2,1,2)$ \\
\hline Weakly important & $(1,3 / 2,2)$ & $(1 / 2,2 / 3,1)$ \\
\hline Strongly more important & $(3 / 2,2,5 / 2)$ & $(2 / 5,1 / 2,2 / 3)$ \\
\hline Very strongly more important & $(2,5 / 2,3)$ & $(1 / 3,2 / 5,1 / 2)$ \\
\hline Absolutely more important & $(5 / 2,3,7 / 2)$ & $(2 / 7,1 / 3,2 / 5)$ \\
\hline & Source: Honarbakhsh et al., (2018)
\end{tabular}

\section{TOPSIS METHOD}

The TOPSIS (Technique for Order Preference by Similarity to Ideal Solution) method has been used very successfully in evaluating companies' financial performance (Üçüncü et al., 2018). It is a multicriteria decision-making technique first developed and applied by Hwang and Yoon (1981, 1995). According to this method, alternatives are determined by their distances from the ideal solution. The goal is to choose the optimal alternative that is closest to the ideal solution, that is, farthest from the 
Lukic, $\mathbf{R}$.

ANALYSIS OF THE EFFICIENCY OF TRADE IN OIL DERIVATIVES IN SERBIA BY APPLYING THE FUZZY AHP-

TOPSIS METHOD

negative ideal solution (Young, 1994). A positive ideal solution maximizes utility, that is, minimizes costs (in relation to a given problem). In contrast, a negative ideal solution maximizes costs, i.e. minimizes utility (Yousefi and Hadi-Vencheh, 2010; Wang and Lee, 2007).

The TOPSIS method consists of 6 steps (Üçüncü et al., 2018).

Step 1: Create an Initial Matrix

The initial matrix Aij " $m$ " denotes the alternative number and " $n$ " the number of criteria:

$$
A_{i j}=\left|\begin{array}{cccc}
a_{11} & a_{12} & \cdots & a_{1 n} \\
a_{21} & a_{22} & \cdots & a_{2 n} \\
\vdots & \vdots & \vdots & \vdots \\
a_{m 1} & a_{m 2} & \cdots & a_{m n}
\end{array}\right|
$$

Step 2: Formation of weighted Normalized Decision Matrix

The normalized decision matrix $\left(R_{i j ;} ; i=1, \ldots, m ; j=1, \ldots, n\right)$ is determined by Equation (14) with the elements of the matrix $A_{i j}$ :

$r_{i j}=\frac{a_{i j}}{\sqrt{\sum_{i=1}^{m} a_{i j}^{2}}}$

$t=1,2,3, \ldots, m \quad j=1,2,3, \ldots, n$

$R_{i j}=\left|\begin{array}{cccc}r_{11} & r_{12} & \cdots & r_{1 n} \\ r_{21} & r_{22} & \cdots & r_{2 n} \\ \vdots & \vdots & \cdots & \vdots \\ r_{m 1} & r_{m 2} & \cdots & r_{m n}\end{array}\right|$

In Equation (15) the weighted measure "j" is represented by $W_{i j .}$. The weighted normalized decision matrix $\left(V_{i j ;} ; i=1, \ldots, m ; j=1, \ldots, n\right)$ was determined using Equation (15) with the elements of the normalized matrix:

$V_{i j}=W_{i j} * r_{i j}$

$i=1,2,3, \ldots, m$

$j=1,2,3, \ldots, n$ 
Step 3: Determine the Positive and Negative-Ideal Solution

The value of the positive-ideal solution $(A+)$ and the negative-ideal solution $(A-)$ is determined from the value of the weighted normalized matrix $\left(V_{i j}\right) . A^{+}$is better and $A^{-}$is a worse performance score.

The value of the positive-ideal solution $\left(\mathrm{A}^{+}\right)$and the negative-ideal solution $\left(\mathrm{A}^{-}\right)$is determined as follows (equation (7) and (8) respectively):

$$
\begin{aligned}
& A^{+}=\left\{v_{i}^{+}, \ldots, v_{n}^{+}\right\}=\left\{\left(\max _{i} v_{i j}, j \in j\right)\left(\min _{i} v_{i j} j \in j^{\prime}\right)\right\} i=1,2, \ldots, m \\
& A^{-}=\left\{v_{i}^{-}, \ldots, v_{n}^{-}\right\}=\left\{\left(\min _{i} v_{i j} j \in j\right)\left(\max _{i} v_{i j} j \in j^{\prime}\right)\right\} i=1,2, \ldots, m
\end{aligned}
$$

where $j$ is related to the benefit criterion, and $j^{\prime}$ is related to the cost criterion.

Step 4: Determination of special measures (i.e. distance of alternatives from ideal and negative-ideal solution)

The distance from the positive-ideal solution $\left(\mathrm{S}_{\mathrm{i}}^{+}\right)$and the negative-ideal solution $\left(\mathrm{S}_{\mathrm{i}}\right)^{-}$for each alternative according to the given criterion is determined using equations (18) and (19).

$$
\begin{aligned}
& S_{i}^{+}=\sqrt{\sum_{j=1}^{n}\left(v_{i j}-v_{j}^{+}\right)^{2}} \\
& S_{i}^{-}=\sqrt{\sum_{j=1}^{n}\left(v_{i j}-v_{j}^{-}\right)^{2}}
\end{aligned}
$$

$$
i=1,2,3, \ldots, m
$$

Step 5: Determination of the coefficient of relative closeness to the ideal solution

Specific measures of positive-ideal solution $\left(\mathrm{S}_{\mathrm{i}}^{+}\right)$and negative-ideal solution $\left(\mathrm{S}_{\mathrm{i}}{ }^{-}\right)$were used to determine the relative closeness to the ideal solution $\left(\mathrm{C}_{i}^{+}\right)$for each decision point. $\mathrm{C}_{i}^{+}$represents the relative closeness to the ideal solution and takes a value in the range $0 \leq \mathrm{C}_{i}+\leq 1$. " $\mathrm{C}^{+}{ }^{+"}=1$ indicates the relative closeness to the positive-ideal solution. " $\mathrm{C}_{i}^{+"}=0$ indicates relative closeness to the negative-ideal solution.

The relative closeness to the ideal solution $\left(\mathrm{C}_{i}^{+} ; \mathrm{i}=1, \ldots, \mathrm{m} ; j=1, \ldots, n\right)$ was determined by using equation (20): 
Lukic, $\mathbf{R}$.

$C_{i}^{+}=\frac{S_{i}^{-}}{S_{i}^{-}+S_{i}^{+}}$

$i=1,2,3, \ldots, m$

Step 6: Sorting of the alternatives according to relative superiority

Determining the relative superiority of the score represents the company's performance. High scores correspond with better performance. The results can be used to determine company rankings within the industry (Üçüncü et al., 2018).

\section{MEASURING THE EFFICIENCY OF TRADE IN OIL DERIVATIES IN SERBIA}

We will perform the Fuzzy AHP - TOPSIS method for measuring the efficiency of trade in oil derivatives in Serbia. In doing so, we will use the following criteria: employees' earnings, assets, capital, sales and net profits. Table 2 shows the original numerical values of the respective criteria.

TABLE 2. SELECTED CRITERIA FOR MEASURING THE EFFICIENCY OF TRADE IN OIL DERIVATIVES IN SERBIA USING THE FUZZY AHP - TOPSIS METHOD, 2018

\begin{tabular}{|l|l|l|l|l|l|}
\hline & $\begin{array}{l}\text { Employees' } \\
\text { earnings (million } \\
\text { dinars) }\end{array}$ & $\begin{array}{l}\text { Assets } \\
\text { (millions of } \\
\text { dinars) }\end{array}$ & $\begin{array}{l}\text { Capital } \\
\text { (million } \\
\text { dinars) }\end{array}$ & $\begin{array}{l}\text { Sales } \\
\text { (million } \\
\text { dinars) }\end{array}$ & $\begin{array}{l}\text { Net profit } \\
\text { (million } \\
\text { dinars) }\end{array}$ \\
\hline $\begin{array}{l}\text { Oil industry of } \\
\text { Serbia - NIS }\end{array}$ & 15245 & 401474 & 81530 & 258523 & 26067 \\
\hline Lukoil & 436 & 5362 & 7837 & 33480 & -248 \\
\hline MOL Serbia & 312 & 15882 & 10426 & 42812 & 655 \\
\hline OMV Serbia & 200 & 12534 & 8254 & 35293 & 813 \\
\hline EKO Serbia & 205 & 7911 & 3728 & 20337 & 199 \\
\hline Knez Petrol & 743 & 7295 & 2082 & 43317 & 388 \\
\hline Euro Petrol & 97 & 2863 & 979 & 9401 & 80 \\
\hline Evolucija 2004 & 48 & 1684 & 73 & 8560 & 16 \\
\hline Naftachem & 130 & 4096 & 1796 & 15118 & 136 \\
\hline
\end{tabular}


Lukic, R.

ANALYSIS OF THE EFFICIENCY OF TRADE IN OIL DERIVATIVES IN SERBIA BY APPLYING THE FUZZY AHP.

TOPSIS METHOD

\begin{tabular}{|l|l|l|l|l|l|}
\hline Euro Gas & 89 & 2328 & 1004 & 3248 & 5 \\
\hline Standard Gas & 73 & 1401 & 100 & 297 & -253 \\
\hline Daki Petrol & 14 & 325 & 38 & 76 & -98 \\
\hline $\begin{array}{l}\text { Horizon } \\
\text { Energy }\end{array}$ & 8 & 519 & 515 & 35 & 8 \\
\hline Miletić Petrol & 28 & 2419 & 415 & 14791 & 70 \\
\hline SPEED & 42 & 2357 & 1466 & 12184 & 30 \\
\hline
\end{tabular}

Source: Business Registers Agency of the Republic of Serbia

Table 3 presents descriptive statistics of the observed criteria in the context of measuring the efficiency of trade in oil derivatives in Serbia by application of the Fuzzy AHP - TOPSIS method.

\section{TABLE 3. DESCRIPTIVE STATISTICS OF OBSERVED CRITERIA IN THE CONTEXT OF MEASURING THE EFFICIENCY OF OIL DERIVATIVES TRADE IN SERBIA BY APPLICATION OF THE FUZZY AHP - TOPSIS} METHOD

\section{Descriptive Statistics}

\begin{tabular}{|l|l|l|l|l|l|}
\hline & $\mathrm{N}$ & Minimum & Maximum & Mean & Std. Deviation \\
\hline Employees' earnings & 15 & 8.00 & 15245.00 & 1178.0000 & 3896.52730 \\
\hline Assets & 15 & 325.00 & 401474.00 & 31230.0000 & 102522.66107 \\
\hline Capital & 15 & 38.00 & 81530.00 & 8016.2000 & 20611.24118 \\
\hline Sales & 15 & 35.00 & 258523.00 & 33164.8000 & 64138.79279 \\
\hline Net profit & 15 & -253.00 & 26067.00 & 1857.8667 & 6703.72901 \\
\hline
\end{tabular}

Source: Author's calculation performed by application of the SPSS software

The data in the table shows that by all criteria the best company is the Oil Industry of Serbia (NIS). It produces above-average results.

Table 4 shows the correlation matrix of observed criteria in the context of measuring the efficiency of trade in oil derivatives in Serbia by application of the Fuzzy AHP - TOPSIS method. 
Lukic, R.

ANALYSIS OF THE EFFICIENCY OF TRADE IN OIL DERIVATIVES IN SERBIA BY APPLYING THE FUZZY AHP-

TOPSIS METHOD

TABLE 4. CORRELATION MATRIX OF OBSERVED CRITERIA IN THE CONTEXT OF MEASURING THE EFFICIENCY OF TRADE IN OIL DERIVATIVES IN SERBIA BY APPLICATION OF THE FUZZY AHP - TOPSIS METHOD

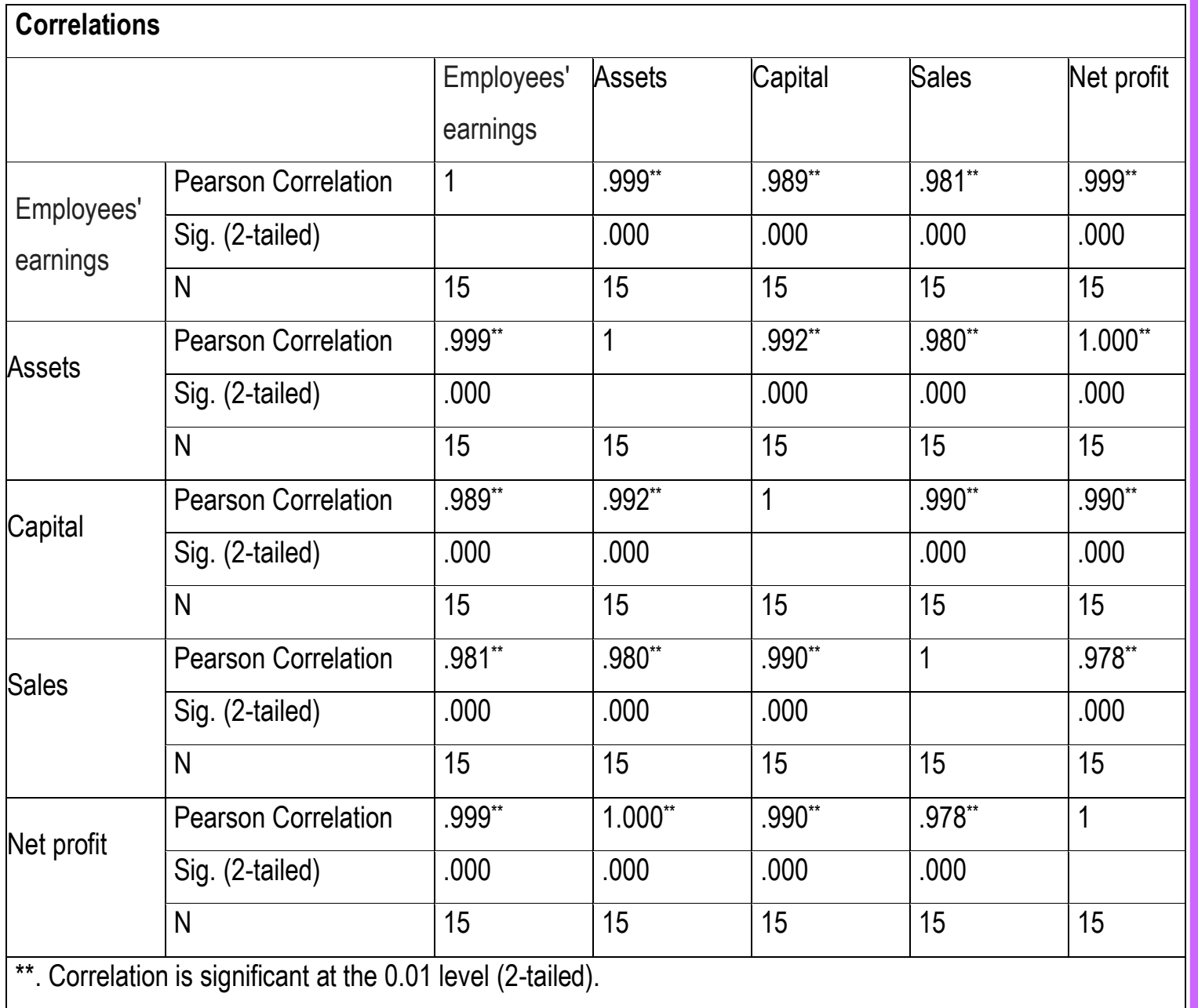

Source: Author's calculation performed by application of the SPSS software

The data in the table below show a high correlation between the observed criteria in the context of measuring the efficiency of oil derivatives trade in Serbia using the Fuzzy AHP - TOPSIS method.

In further presentations of the treated problem using the Fuzzy AHP method we will determine the weight coefficients of the criteria used in the context of measuring the efficiency of trade in oil derivatives in Serbia using the Fuzzy AHP-TOPSIS method. (Data processing was performed using Chang Fuzzy AHP with Consistency Ratio.xlsx.)

Table 5 shows the linguistic scale of values used in this paper. 
Lukic, $\mathbf{R}$.

ANALYSIS OF THE EFFICIENCY OF TRADE IN OIL DERIVATIVES IN SERBIA BY APPLYING THE FUZZY AHP-

TOPSIS METHOD

TABLE 5. MEMBERSHIP FUNCTION OF LINGUISTIC SCALE (EXAMPLE)

\begin{tabular}{|l|l|l|}
\hline Fuzzy number & Linguistic & Scale of fuzzy number \\
\hline 9 & Perfect & $(8,9,10)$ \\
\hline 8 & Absolute & $(7,8,9)$ \\
\hline 7 & Very good & $(6,7,8)$ \\
\hline 6 & Fairly good & $(5,6,7)$ \\
\hline 5 & Good & $(4,5,6)$ \\
\hline 4 & Preferable & $(3,4,5)$ \\
\hline 3 & Not bad & $(2,3,4)$ \\
\hline 2 & Weak advantage & $(1,2,3)$ \\
\hline 1 & Equal & $(1,1,1)$ \\
\hline
\end{tabular}

Source: Chang Fuzzy AHP with Consistency Ratio.xlsx

Table 6 shows the initial comparison matrix.

TABLE 6. INITIAL COMPARISON MATRIX

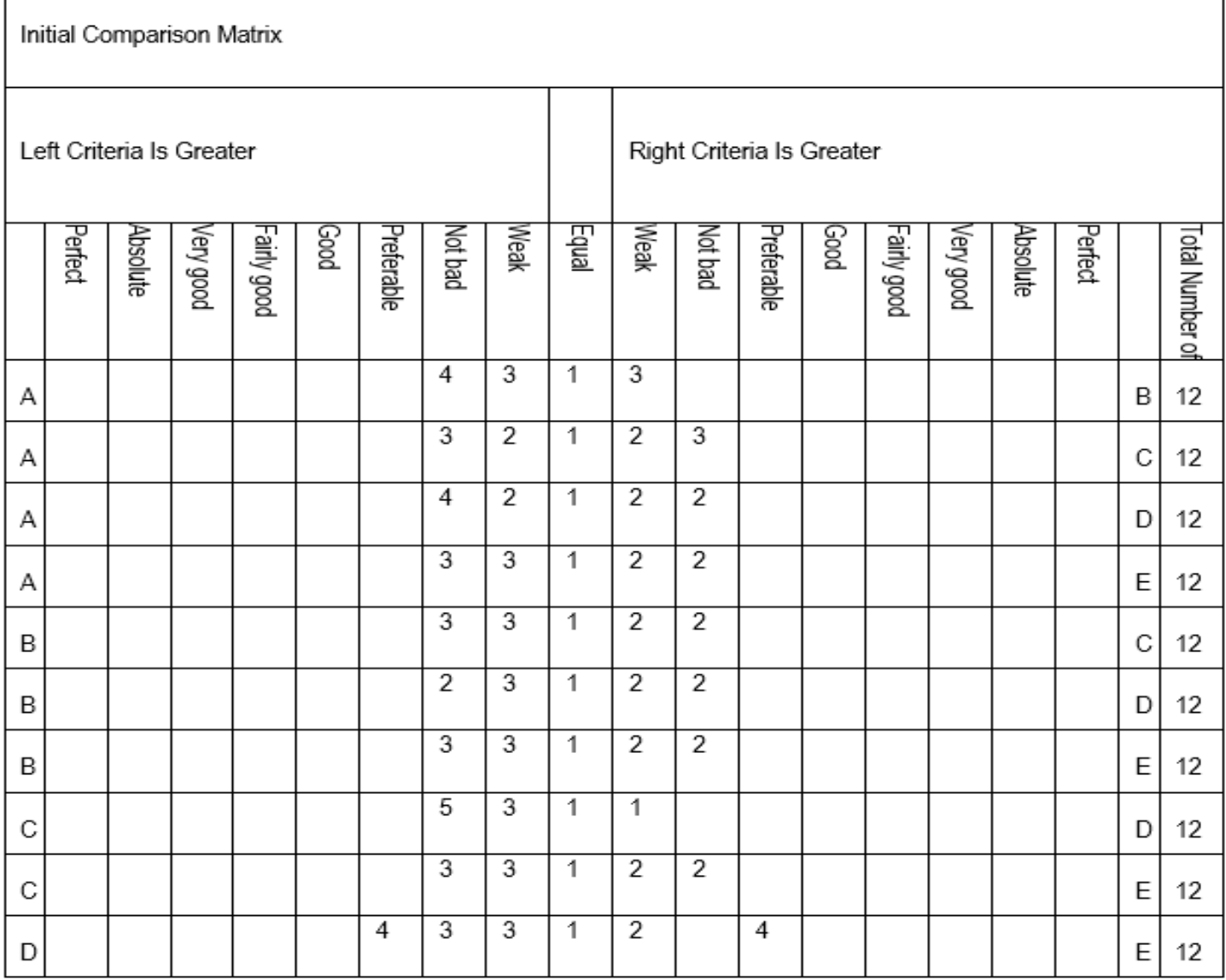

Source: Author's calculation performed by application of Chang Fuzzy AHP With Consistency Ratio.xlsx. Some criteria labels are: A - employees' earnings, B - assets, C - capital, D - sales and E - net profit 
Lukic, $\mathbf{R}$.

ANALYSIS OF THE EFFICIENCY OF TRADE IN OIL DERIVATIVES IN SERBIA BY APPLYING THE FUZZY AHP-

TOPSIS METHOD

Table 7 shows the integrated fuzzy comparison matrix.

TABLE 7. INTEGRATED FUZZY COMPARISON MATRIX

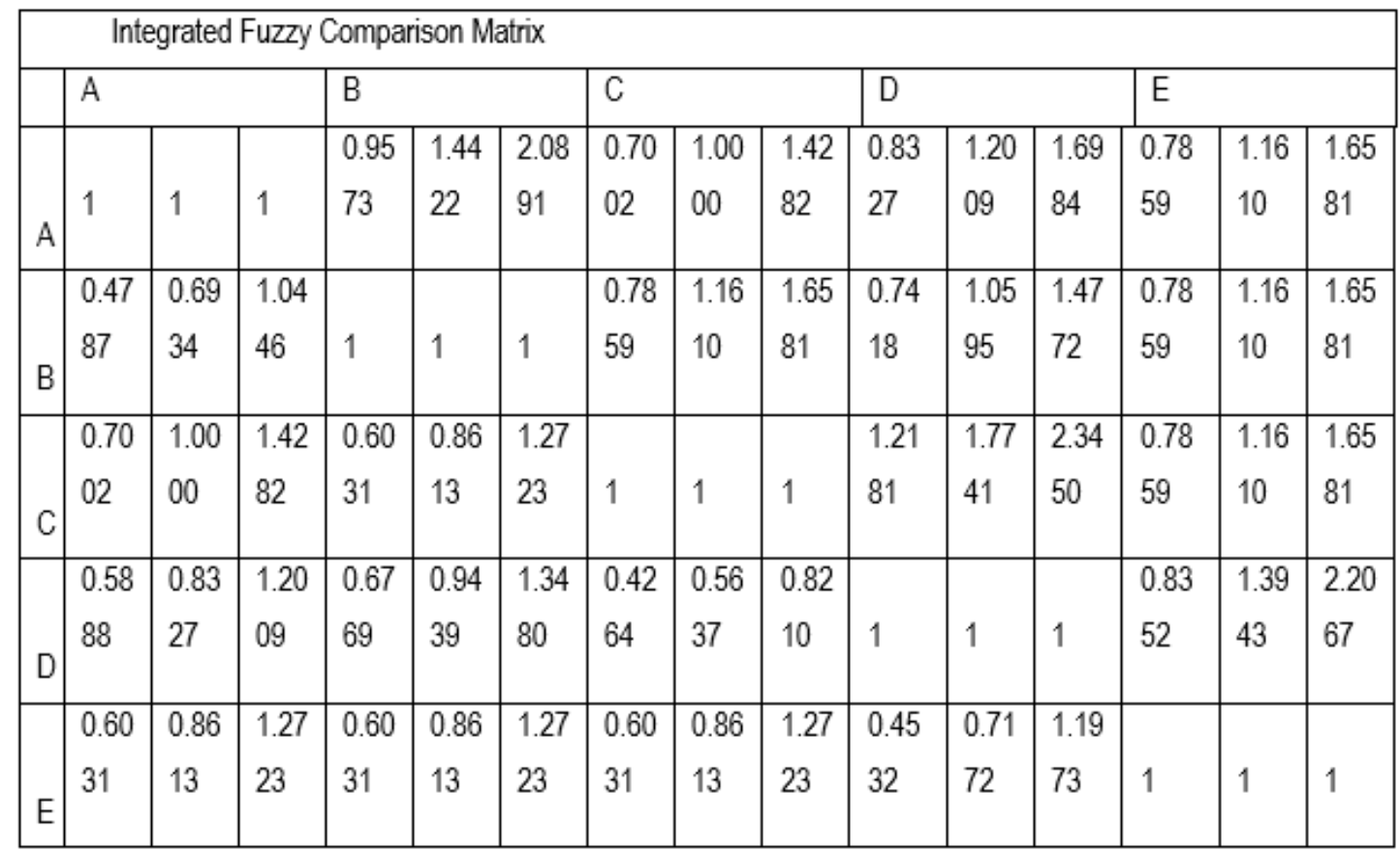

\begin{tabular}{|c|c|c|c|c|c|c|}
\hline & \multicolumn{3}{|c|}{ Fuzzy Sum of Each Row } & \multicolumn{3}{|c|}{ Fuzzy Synthetic Extent } \\
\hline & 4.2762 & 5.8042 & 7.8738 & 0.1222 & 0.2257 & 0.4108 \\
\hline & 3.7924 & 5.0749 & 6.8381 & 0.1083 & 0.1974 & 0.3568 \\
\hline & 4.3073 & 5.7964 & 7.7036 & 0.1230 & 0.2254 & 0.4020 \\
\hline & 3.5274 & 4.7346 & 6.5766 & 0.1008 & 0.1841 & 0.3431 \\
\hline & 3.2624 & 4.3011 & 6.0144 & 0.0932 & 0.1673 & 0.3138 \\
\hline Sum & 19.1656 & 25.7112 & 35.0066 & & & \\
\hline
\end{tabular}


Lukic, R.

ANALYSIS OF THE EFFICIENCY OF TRADE IN OIL DERIVATIVES IN SERBIA BY APPLYING THE FUZZY AHPTOPSIS METHOD

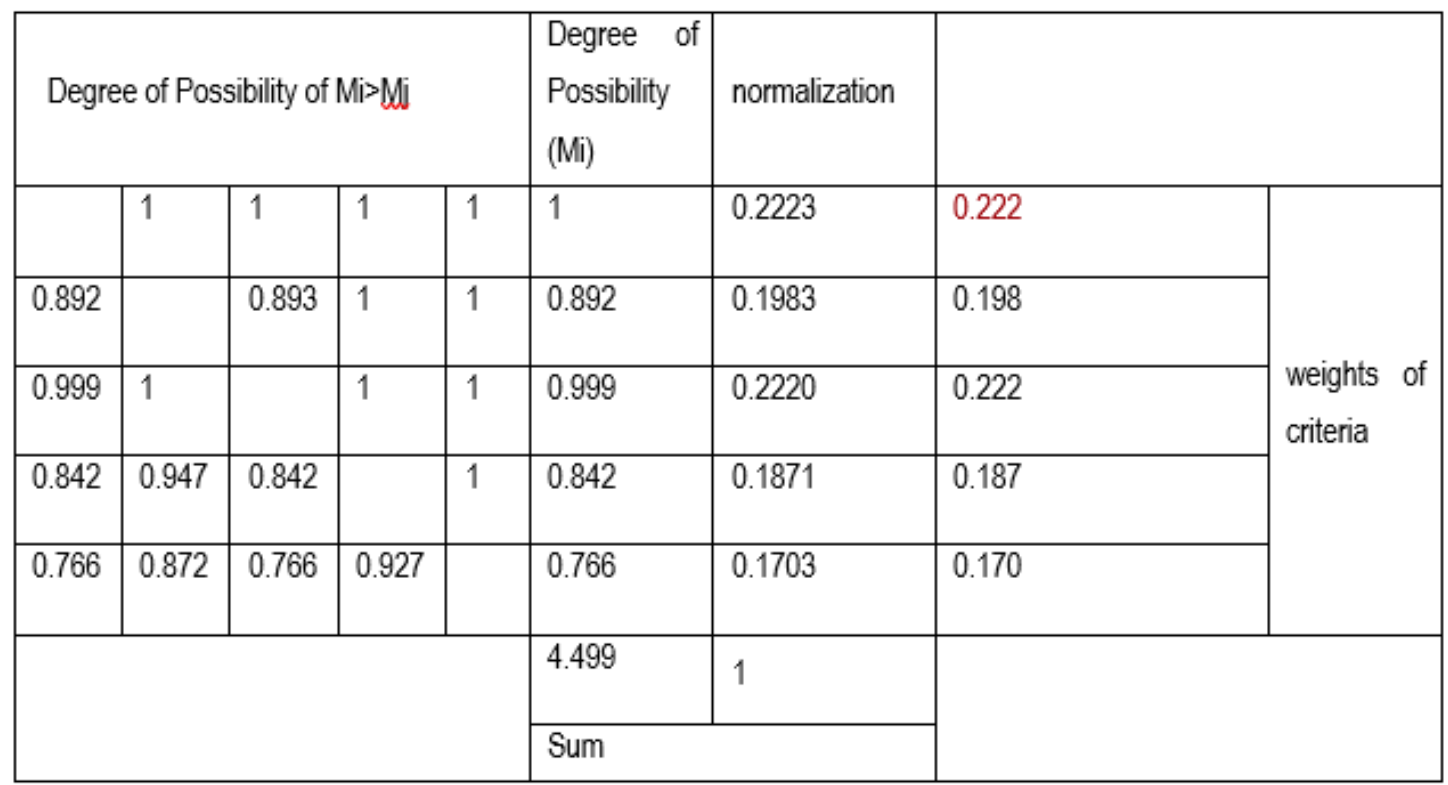

\begin{tabular}{|l|l|l|l|}
\hline & & & \multirow{2}{*}{ Compare with $\underline{0.1}$, They should be less than $\underline{0.1}$} \\
\hline \multicolumn{2}{|l|}{ Consistency Ratio (CRm) } & 0.0173 & \\
\hline \multicolumn{2}{|l|}{ Consistency Ratio (CRg) } & 0.0439 & \\
\hline & & & \\
\hline
\end{tabular}

Source: Author's calculation performed by application of Chang Fuzzy AHP With Consistency Ratio.xlsx. Some criteria labels are: A - employee earnings, B - assets, C - capital, D - sales and E - net profit

The data in the table below shows that in this particular case, the most important criterion is employees' salaries and capital, respectively.

We will use the obtained weights coefficients of the observed criteria using the Fuzzy AHP method when applying the TOPSIS method in evaluating the efficiency of trade in oil derivatives in Serbia. (Data processing using the TOPSIS method was performed using ARAS Software.xlsx.)

Table 8 shows the initial decision matrix.

TABLE 8. INITIAL DECISION MATRIX

\begin{tabular}{|l|l|l|l|l|l|}
\hline weights of criteria & 0.222 & 0.198 & 0.222 & 0.187 & 0.17 \\
\hline kind of criteria & -1 & -1 & -1 & 1 & 1 \\
\hline & C1 & C2 & C3 & C4 & C5 \\
\hline Oil industry of Serbia(NIS) & 15245 & 401474 & 81530 & 258523 & 26067 \\
\hline Lukoil & 436 & 5362 & 7837 & 33480 & -248 \\
\hline MOL Serbia & 312 & 15882 & 10426 & 42812 & 655 \\
\hline
\end{tabular}


Lukic, $R$.

ANALYSIS OF THE EFFICIENCY OF TRADE IN OIL DERIVATIVES IN SERBIA BY APPLYING THE FUZZY AHPTOPSIS METHOD

\begin{tabular}{|l|l|l|l|l|l|}
\hline OMV Serbia & 200 & 12534 & 8254 & 35293 & 813 \\
\hline EKO Serbia & 205 & 7911 & 3728 & 20337 & 199 \\
\hline Knez Petrol & 743 & 7295 & 2082 & 43317 & 388 \\
\hline Euro Petrol & 97 & 2863 & 979 & 9401 & 80 \\
\hline Evolucija 2004 & 48 & 1684 & 73 & 8560 & 16 \\
\hline Naftachem & 130 & 4096 & 1796 & 15118 & 136 \\
\hline Euro Gas & 89 & 2328 & 1004 & 3248 & 5 \\
\hline Standard Gas & 73 & 1401 & 100 & 297 & -253 \\
\hline Daki Petrol & 14 & 325 & 38 & 76 & -98 \\
\hline Horizon Energy & 8 & 519 & 515 & 35 & 8 \\
\hline Miletić Petrol & 28 & 2419 & 415 & 14791 & 70 \\
\hline SPEED & 42 & 2357 & 1466 & 12184 & 30 \\
\hline
\end{tabular}

\begin{tabular}{|l|l|l|l|l|l|}
\hline MAX & 15245 & 401474 & 81530 & 258523 & 26067 \\
\hline MIN & 8 & 325 & 38 & 35 & -253 \\
\hline 0-Optimal Value & 8 & 325 & 38 & 258523 & 26067 \\
\hline
\end{tabular}

Source: Author's calculation performed by application of ARAS Software.xlsx. Certain criteria labels mean: C1 employee earnings, C2 - assets, C3 - capital, C4 - sales and C5 - net profit

Table 9 shows the normalized decision matrix.

TABLE 9. NORMALIZED DECISION MATRIX

\begin{tabular}{|l|l|l|l|l|l|}
\hline weights of criteria & 0.222 & 0.198 & 0.222 & 0.187 & 0.17 \\
\hline kind of criteria & -1 & -1 & -1 & 1 & 1 \\
\hline & $\mathrm{C} 1$ & $\mathrm{C} 2$ & $\mathrm{C} 3$ & $\mathrm{C} 4$ & $\mathrm{C} 5$ \\
\hline 0-Optimal Value & 0.2708 & 0.2598 & 0.3094 & 0.3420 & 0.4780 \\
\hline Oil industry of Serbia (NIS) & 0.0001 & 0.0002 & 0.0001 & 0.3420 & 0.4780 \\
\hline Lukoil & 0.0050 & 0.0157 & 0.0015 & 0.0443 & 0 \\
\hline MOL Serbia & 0.0069 & 0.0053 & 0.0011 & 0.0566 & 0.0120 \\
\hline OMV Serbia & 0.0108 & 0.0067 & 0.0014 & 0.0467 & 0.0149 \\
\hline EKO Serbia & 0.0106 & 0.0107 & 0.0032 & 0.0269 & 0.0036 \\
\hline Knez Petrol & 0.0029 & 0.0116 & 0.0056 & 0.0573 & 0.0071 \\
\hline Euro Petrol & 0.0223 & 0.0295 & 0.0120 & 0.0124 & 0.0015 \\
\hline Evolucija 2004 & 0.0451 & 0.0501 & 0.1611 & 0.0113 & 0.0003 \\
\hline Naftachem & 0.0167 & 0.0206 & 0.0065 & 0.0200 & 0.0025 \\
\hline
\end{tabular}


Lukic, R.

ANALYSIS OF THE EFFICIENCY OF TRADE IN OIL DERIVATIVES IN SERBIA BY APPLYING THE FUZZY AHP. TOPSIS METHOD

\begin{tabular}{|l|l|l|l|l|l|}
\hline Euro Gas & 0.0243 & 0.0363 & 0.0117 & 0.0043 & 0.0001 \\
\hline Standard Gas & 0.0297 & 0.0603 & 0.1176 & 0.0004 & 0 \\
\hline Daki Petrol & 0.1548 & 0.2598 & 0.3094 & 0.0001 & 0 \\
\hline Horizon Energy & 0.2708 & 0.1627 & 0.0228 & 0.0000 & 0.0001 \\
\hline Miletić Petrol & 0.0774 & 0.0349 & 0.0283 & 0.0196 & 0.0013 \\
\hline SPEED & 0.0516 & 0.0358 & 0.0080 & 0.0161 & 0.0006 \\
\hline
\end{tabular}

Source: Author's calculation performed by application of ARAS Software.xlsx. Certain criteria labels mean: C1 employee earnings, C2 - assets, C3 - capital, C4 - sales and C5 - net profit

Table 10 shows the normalized decision weight matrix.

TABLE 10. NORMALIZED WEIGHT DECISION MATRIX

\begin{tabular}{|l|l|l|l|l|l|}
\hline & C1 & C2 & C3 & C4 & C5 \\
\hline 0-Optimal Value & 0.0601 & 0.0514 & 0.0687 & 0.0639 & 0.0813 \\
\hline Oil industry of Serbia (NIS) & 0.0000 & 0.0000 & 0.0000 & 0.0639 & 0.0813 \\
\hline Lukoil & 0.0011 & 0.0031 & 0.0003 & 0.0083 & 0 \\
\hline MOL Serbia & 0.0015 & 0.0011 & 0.0003 & 0.0106 & 0.0020 \\
\hline OMV Serbia & 0.0024 & 0.0013 & 0.0003 & 0.0087 & 0.0025 \\
\hline EKO Serbia & 0.0023 & 0.0021 & 0.0007 & 0.0050 & 0.0006 \\
\hline Knez Petrol & 0.0006 & 0.0023 & 0.0013 & 0.0107 & 0.0012 \\
\hline Euro Petrol & 0.0050 & 0.0058 & 0.0027 & 0.0023 & 0.0002 \\
\hline Evolucija 2004 & 0.0100 & 0.0099 & 0.0358 & 0.0021 & 0.0000 \\
\hline Naftachem & 0.0037 & 0.0041 & 0.0015 & 0.0037 & 0.0004 \\
\hline Euro Gas & 0.0054 & 0.0072 & 0.0026 & 0.0008 & 0.0000 \\
\hline Standard Gas & 0.0066 & 0.0119 & 0.0261 & 0.0001 & 0 \\
\hline Daki Petrol & 0.0344 & 0.0514 & 0.0687 & 0.0000 & 0 \\
\hline Horizon Energy & 0.0601 & 0.0322 & 0.0051 & 0.0000 & 0.0000 \\
\hline Miletić Petrol & 0.0172 & 0.0069 & 0.0063 & 0.0037 & 0.0002 \\
\hline SPEED & 0.0115 & 0.0071 & 0.0018 & 0.0030 & 0.0001 \\
\hline
\end{tabular}

Source: Author's calculation performed by application of ARAS Software.xlsx. Certain criteria labels mean: C1 employee earnings, C2 - assets, C3 - capital, C4 - sales and C5 - net profit 
Lukic, $\mathbf{R}$.

ANALYSIS OF THE EFFICIENCY OF TRADE IN OIL DERIVATIVES IN SERBIA BY APPLYING THE FUZZY AHP-

TOPSIS METHOD

Table 11 and Figure 3 show the ranked decision matrix.

TABLE 11. RANKED DECISION MATRIX

\begin{tabular}{|c|c|c|c|c|}
\hline & $S$ & $\mathrm{~K}$ & $\mathrm{~K}$ & Ranking \\
\hline 0-Optimal Value & 0.3255 & 1 & 1 & \\
\hline $\begin{array}{l}\text { Oil industry of Serbia } \\
\text { (NIS) }\end{array}$ & 0.1453 & 0.4465 & 0.4465 & 2 \\
\hline Lukoil & 0.0128 & 0.0394 & 0.0394 & 14 \\
\hline MOL Serbia & 0.0155 & 0.0476 & 0.0476 & 11 \\
\hline OMV Serbia & 0.0153 & 0.0471 & 0.0471 & 12 \\
\hline EKO Serbia & 0.0108 & 0.0332 & 0.0332 & 15 \\
\hline Knez Petrol & 0.0161 & 0.0495 & 0.0495 & 8 \\
\hline Euro Petrol & 0.0160 & 0.0493 & 0.0493 & 9 \\
\hline Evolucija 2004 & 0.0579 & 0.1778 & 0.1778 & 4 \\
\hline Naftachem & 0.0134 & 0.0412 & 0.0412 & 13 \\
\hline Euro Gas & 0.0160 & 0.0492 & 0.0492 & 10 \\
\hline Standard Gas & 0.0447 & 0.1373 & 0.1373 & 5 \\
\hline Daki Petrol & 0.1545 & 0.4747 & 0.4747 & 1 \\
\hline Horizon Energy & 0.0974 & 0.2994 & 0.2994 & 3 \\
\hline Miletić Petrol & 0.0343 & 0.1053 & 0.1053 & 6 \\
\hline SPEED & 0.0234 & 0.0720 & 0.0720 & 7 \\
\hline
\end{tabular}

Source: Author's calculation performed by application of ARAS Software.xlsx.

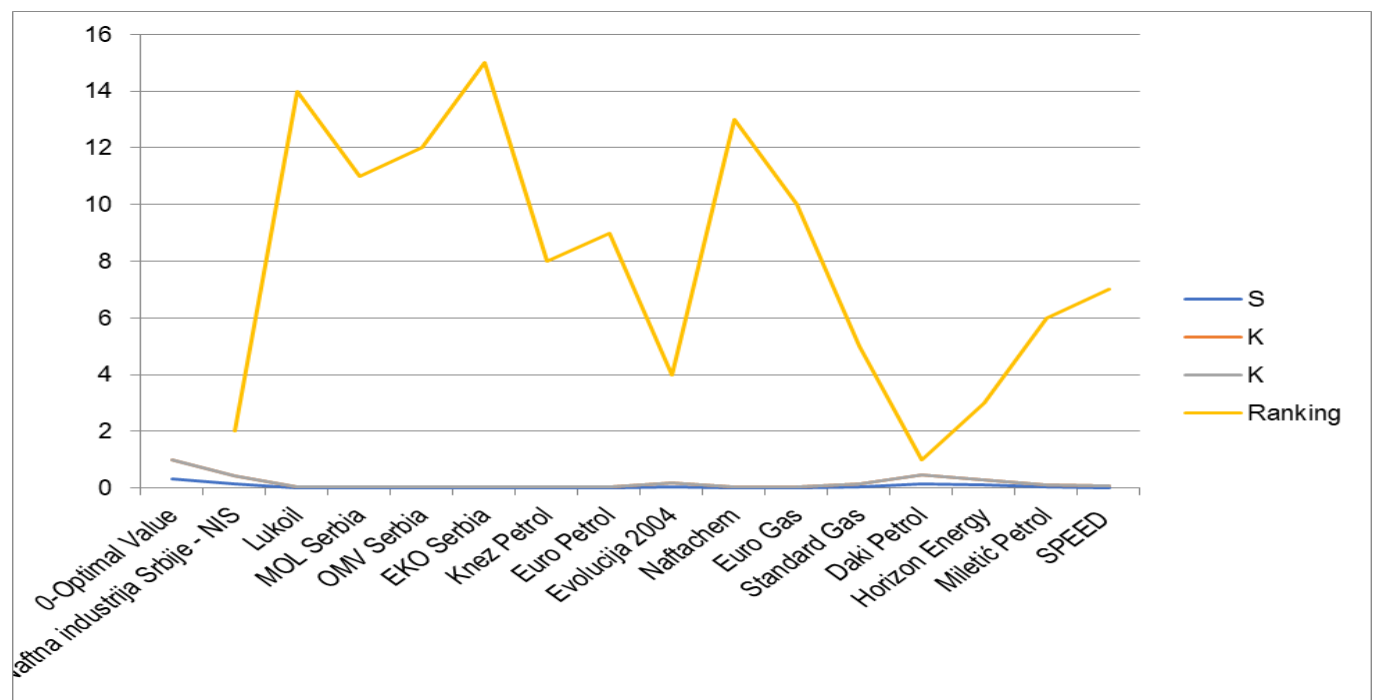

FIGURE 3. RANKED DECISION MATRIX

Source: Author's calculation 
Therefore, the most efficient are Daki Petrol, Oil Industry of Serbia (NIS) and Horizon Petrol. The most inefficient companies are Eko Serbia, Lukoil and Naftachem. Other observed companies in the oil derivatives sector are "moderately" efficient.

\section{CONCLUSIONS}

Based on the conducted analysis of the efficiency of trade in oil derivatives in Serbia by integrated Fuzzy AHP-TOPSIS method, it can be concluded that of all the observed criteria (employees' earnings, assets, capital, sales and net profit) the most significant are employees' earnings and capital, respectively.

Furthermore, the most efficient companies are Daki Petrol, Oil Industry of Serbia (NIS), and Horizon Petrol while the most inefficient companies are Eko Serbia, Lukoil and Naftachem. Other observed companies which do trading business in oil derivatives in Serbia are "moderately" efficient.

In order to improve their efficiency in the future, it is necessary to manage assets, capital, sales and profits as efficiently as possible. Also, it is necessary that employees' earnings are at an "acceptable level" in accordance with the business conditions in a given business environment.

\section{REFERENCES}

Büyüközkan, G., Ertay, T., Kahraman, C. and Ruan, D. (2004). Determining the importance weights for the design requirements in the house of quality using the fuzzy analytic network approach. International Journal of Intelligent systems, 19: 443-461.

Chang, D. Y. (1992). Extent analysis and synthetic decision. In: Phua KH, Wang CM, Yeong WY, Leong TY (eds): Optimization techniques and applications (pp 352-5). Singapore: World Scientific Pub. Co.

Chang, D.Y.(1996). Application of the extent analysis method on fuzzy AHP. European journal of operational research, 95(3): 649-655.

Harker P. T. and Vargas L.G. (1987). The Theory of Ratio Scale Estimation: Saaty's Analytic Hierarchy Process. Management Science, 33(11): 1383-1403.

Honarbakhsh, M, Jahangiri, M, Ghaem, H, and Farhadi, P. (2018). Respiratory protection program compliance in Iranian hospitals: application of fuzzy analytical hierarchy process. Workplace Health \&Safety, 66: 173-82.

Hwang C.L., Yoon K.S. (1981). Multiple attribute decision making: methods and applications. Berlin: Springer.

Hwang, C. L., Yoon, K.P. (1995). Multiple Attribute Decision Making: An Introduction. Paperback / Sage Publications.

Keener, M.H. (August 2013). Predicting the Financial Failure Of Retail Companies In The United States. Journal of Business \& Economics Research, 11(8): 373-380.

Kwong, C.K., Bai, H. (2003). Determining the importance weights for the customer requirements in QFD 
using a fuzzy AHP with an ex-tent analysis approach. IIE Transactions, 35 (7): 619-625.

Lukic, R. (2011). Evaluacija poslovnih performansi u maloprodaji. Beograd: Ekonomski fakultet.

Lukic, R. (2018a). The Analysis of the Operative Profit Margin of Trade Companies in Serbia. Review of International Comparative Management, 19(9): 458-478.

Lukic, R. (2018b). Analiza prinosa na investicije trgovine Srbije: Aktuelno stanje i perspektive. Zbornik matice srpske za društvene nauke, 168 (4/2018): 777-803.

Lukić, R. (2019). Analiza efikasnosti trgovinskih preduzeća u Srbiji. Zbornik radova Ekonomskog fakulteta Brčko, 13(1): 15-27.

Martino, G. et al. (2017). Supply Chain Risk Assessment in the Fashion retail Industry: An Analytic Network Process Approach. International Journal of Applies research, 12(2): 140-154.

Saaty, T.L. (1970). Optimization in integers and Related Extremal Problems. New York: MCGraw-Hill.

Saaty T.L.(1980). The analytic hierarchy process. New York: McGraw-Hill.

Saaty, T.L. (2008). Decision Making With The Analytic Hierarchy Process. Int J ServSci, 1(1): 83-98.

Saaty, T.L. (1986). Axiomatic foundation of the Analytic Hierarchy Process. Management Science, 32(7):841-855.

Saaty, T.L. and Vargas, L.G. (2001). Models, Methods, Concepts \& Applications of the Analytic Hierarchy Process. International Series in Operations Research and Management Science, Springer.

Üçüncü, T., Akyüz, K. C., Akyüz, İ., Bayram, B. Ç., VeErsen, N. (2018). Evaluation Of Financial Performance Of Paper Companies Traded At BIST With TOPSIS Method. Kastamonu University Journal Of Forestry Faculty, 18(1): 92-98.

vanLaarhoven, P.J.M., and Pedrycs, W. (1983). A fuzzy extension of Saaty's priority theory. Fuzzy Sets and Systems, 11: 229-241.

Wang, Y. J. and Lee, H. S. (2007). Generalizing TOPSIS for fuzzy multiple-criteria group decisionmaking. Computers and Mathematics with Applications, 53: 1762-1772.

Young, J. L., Ting, Y. L. and Hwang, C. L. (1994). TOPSIS for MODM. European Journal of Operational Research, North-Holland, 76: 486-500.

Yousefi, A. veHadi-Vencheh, A. (2010). An integrated group decision making model and its evaluation by DEA for automobile industry. Expert Systems with Applications, 37(8): 543-556.

Zhu K-J, Jing Y, Chang D-Y. (1999). A discussion on extent analysis method and applications of fuzzy AHP. Euro J Oper Res, 116(2):450 - 456. 